\title{
Interleukin 1 dose-dependently affects the biosynthesis of (pro)insulin in isolated rat islets of Langerhans
}

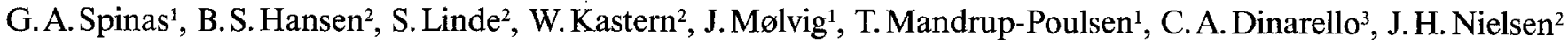 \\ and J. Nerup ${ }^{1}$
}

${ }^{1}$ Steno Memorial Hospital and ${ }^{2}$ Hagedorn Research Laboratory, Gentofte, Denmark;

${ }^{3}$ Department of Medicine, Tufts University School of Medicine, Boston, Massachusetts, USA

Summary. Human crude and recombinant interleukin 1 (IL1) was found to dose- and time-dependently affect the biosynthesis of (pro)insulin in isolated rat islets of Langerhans. Incubation of rat islets with either $0.5 \mathrm{U} / \mathrm{ml}$ or $5 \mathrm{U} / \mathrm{ml}$ of crude IL-1 for $1 \mathrm{~h}$ had no detectable effect on (pro)insulin biosynthesis. After 24 hours of exposure $0.5 \mathrm{U} / \mathrm{ml}$ of crude or $0.6 \mathrm{ng} / \mathrm{ml}$ of recombinant IL-1 (beta) increased the (pro)insulin biosynthesis by $42 \%$ and $58 \%$, respectively, whereas a 10-fold greater concentration of IL-1 decreased the (pro)insulin biosynthesis by $74 \%$ and $89 \%$, respectively. The increase in (pro)insulin biosynthesis was accompanied by an increase in total protein biosynthesis indicating a nonspecific stimulatory action of low IL- 1 concentrations. In contrast, high IL-1 concentrations caused a more selective decrease of the (pro)insulin biosynthesis when compared to the total protein biosynthesis. In addition, low IL-1 concentrations were found to increase and high concentrations to decrease the relative levels of pre-proinsulin mRNA suggesting that IL-1 may act both at a pre- and post-translational level of insulin biosynthesis.

Key words: Interleukin 1, pancreatic islets, preproinsulin mRNA, proinsulin biosynthesis, Type 1 (insulin-dependent) diabetes mellitus.
Interleukin 1 (IL-1) is a pluripotent peptide hormone produced mainly by activated macrophages, but also by other lymphoid and nonlymphoid cells, such as B cells, keratinocytes, epithelial and astroglial cells. IL-1 plays a central role in lymphokine production and exerts a wide range of biological effects on various cell types, e.g. B lymphocytes, fibroblasts, synovial cells, hepatic cells, and hypothalamic cells [1-3].

We have previously shown that IL-1 dose- and time-dependently affects insulin release from isolated islets of Langerhans. Whereas low IL-1 doses increase insulin release and islet insulin content [4], higher concentrations during prolonged incubation exert a toxic effect on B cells $[5,6]$. Since both insulin release and insulin content were concomitantly affected, we suggested that IL-1 may act on the biosynthesis of insulin in the $B$ cells.

In the present study the effect of different IL-1 concentrations on the (pro)insulin biosynthesis in isolated rat islets of Langerhans was investigated.

We report here that low IL-1 concentrations increase and high IL-1 concentrations decrease the biosynthesis of (pro)insulin. In addition, preproinsulin mRNA-levels are increased at low IL-1 concentrations indicating a pretranslational action of the cytokine.

\section{Materials and methods}

\section{IL-1 preparations}

Preparation of crude human $I L-1$. Crude monocyte IL-1 was produced by stimulation of human macrophages (Mø) with $2 \mu \mathrm{g} / \mathrm{ml}$ lipopolysaccharide (LPS) or by phytohaemagglutinin (PHA) pulsing of peripheral blood mononuclear cells as previously described [4, 7]. The crude supernatants contained approximately 150 lymphocyte activating factor units (LAF)/ $\mathrm{ml}$ [4] and showed identical dose-response effects on insulin release from isolated rat islets in culture. One LAF-unit is defined as doubling of the mitogen response of murine thymocytes. Since the crude supernatants were diluted approximately 200 times, the maximal concentrations of LPS was $10 \mathrm{ng} / \mathrm{ml}$, or $25 \mathrm{ng} / \mathrm{ml}$ of PHA. Previous studies have shown that neither $0.1-10 \mu \mathrm{g} / \mathrm{ml}$ of LPS nor concentrations up to $250 \mathrm{ng} / \mathrm{ml}$ of PHA interfere with islet function [8].

The islet cytotoxic activity of either crude IL-1 preparations. could be neutralized by an antibody to human monocyte IL-1 [6, unpublished data].

Preparation of recombinant $I L-1$ ( $r I L-1)$. The rIL-1 was expressed in Escherichia coli and consisted of the polypeptide sequence 112-269 $(17.5 \mathrm{kD})$ of the predominant $\mathrm{pI} 7$ or beta form as described previously [9]. The rIL-1 was purified to homogeneity and contained $20 \mathrm{mg}$ of protein $/ 1$, and the specific activity of the preparation was approximately $250 \times 10^{6} \mathrm{LAF}-\mathrm{U} / \mathrm{g}$. Endotoxin contamination was less than $60 \mathrm{pg} / \mathrm{mg}$ IL-1. 


\section{Islet isolation and culture}

Rat islets were isolated from collagenase-treated pancreata of outbred newborn (5-7 days old) Wistar rats (Møllegard, Lille Skensved, Denmark) and pre-cultured for 6-8 days as described in detail elsewhere [10]. The precultured islets were pooled, washed once in medium RPMI 1640 (Flow Laboratories, Irvine, Scotland) and distributed randomly in plastic Petri dishes (Falcon, Oxnard, Calif, USA) at a concentration of 30 islets $/ \mathrm{ml}$ in medium supplemented with $20 \mathrm{mmol} / 1$ HEPES buffer, $11 \mathrm{mmol} / 1$ glucose, $100000 \mathrm{IU} / 1$ penicillin, $100 \mathrm{mg} / 1$ streptomycin and $0.5 \%$ normal human serum (NHS). The islets were incubated free-floating for $1 \mathrm{~h}$, $24 \mathrm{~h}$ or 6 days in humidified atmosphere at $37^{\circ} \mathrm{C}$ with or without the addition of either crude or recombinant IL-1. Each condition was set up in quadruplicate. After $1 \mathrm{~h}, 24 \mathrm{~h}$ or 6 days of culture, $100 \mu \mathrm{l}$ of culture medium was sampled for determination of insulin by RIA [11] using rat insulin as standard (NOVO Research Institute, Bagsværd, Denmark). The interassay coefficient of variation for the radioimmunoassay was less than $6 \%$.

\section{Determination of (pro)insulin biosynthesis}

In order to determine the biosynthesis of (pro)insulin $[12,13]$, the islets were harvested, washed in Hanks' balanced salt solution (HBSS, Flow) containing $1 \%$ human serum albumin and $20 \mathrm{mmol} / 1$ glucose and incubated for $3 \mathrm{~h}$ in $100 \mu \mathrm{l} \mathrm{HBSS}$ with $1 \%$ human serum albu$\mathrm{min}, 20 \mathrm{mmol} / 1$ glucose and $500 \mu \mathrm{Ci} / \mathrm{ml}$ of $\mathrm{L}-\left(4.5{ }^{3} \mathrm{H}\right)$ leucine $(130 \mathrm{Ci} / \mathrm{mmol}$ ) (Amersham, UK). The islets were then washed in HBSS with $10 \mathrm{mmol} / 1$ unlabelled leucine and sonicated in $200 \mu \mathrm{l}$ of $0.2 \mathrm{~mol} / 1$ glycine ( $\mathrm{pH} 8.8), 2.5 \mathrm{mg} / \mathrm{ml}$ bovine serum albumin (BSA), and $0.5 \%$ Nonidet P-40. Radioactively labelled (pro)insulin was determined by immunoprecipitation of $20 \mu l$ islet homogenate corresponding to 0.5 islet with $50 \mu \mathrm{l}$ of guinea pig anti-insulin serum at a dilution of 1:100 for $24 \mathrm{~h}$ and separation of the antibody-antigen complexes by the addition of $100 \mu$ lof protein A-Sepharose $(50 \mathrm{mg}$ / $\mathrm{ml}$, Pharmacia, Uppsala, Sweden) for $30 \mathrm{~min}$ [14]. The precipitate was resuspended in $250 \mu 11 \mathrm{~mol} / 1$ acetic acid containing $2.5 \mathrm{mg} / \mathrm{ml}$ bovine serum albumin, and counted in a liquid scintillation counter after addition of $10 \mathrm{ml}$ Aquasol 2 (New England Nuclear, Boston, Mass, USA). Non specific binding of radioactive material was determined by precipitation with non-immune serum. This amounted to $1.6 \%$ of the total radioactivity. Total protein biosynthesis was assessed after precipitation of $20 \mu \mathrm{l}$ of the islet homogenate containing $2.5 \mathrm{mg} / \mathrm{ml} \mathrm{BSA}$ as carrier protein with $10 \%$ trichloracetic acid (TCA) for $40 \mathrm{~min}$.

\section{Reversed-phase high performance liquid chromatography (RP-HPLC) of the islet homogenates}

The polypeptide content in the islet homogenates of 2 experiments was analysed by reversed-phase high performance liquid chromatography (RP-HPLC) using a modification (see legend to Fig. 2) of a previously described method for RP-HPLC separation of porcine insulin and insulin derivatives [15]. Identification of individual peaks was based upon retention time of authentic standards of rat insulin 1 and 2 and bovine glucagon, amino acid sequencing of C-peptides 1 and 2, or insulin radioimmunoassay of insulin and the presumed proinsulin peaks. Since a rat proinsulin standard is not available, the proinsulin peak was identified by its immunoreactivity and on the basis of its disappearance concomitantly with equimolar increases of the insulin and C-peptide peaks during a 30-60 min chase period after pulse labelling with ${ }^{3} \mathrm{H}$-leucine and ${ }^{35} \mathrm{~S}$-methionine [16]. A similar method was described recently [17].

\section{Determination of preproinsulin $m R N A$}

In separate experiments, rat islets precultured for 7 days as described above were incubated in the presence or absence of either $0.6 \mathrm{ng} / \mathrm{ml}$, $1.2 \mathrm{ng} / \mathrm{ml}$ or $6 \mathrm{ng} / \mathrm{ml} \mathrm{rIL}-1$ for 4 or $24 \mathrm{~h}$. The time points were cho- sen on the basis of the results obtained in the biosynthesis experiments. The islets were then washed, and the preproinsulin mRNA determined by means of a cytoplasmic dot hybridization method [18]. In brief, islets were resuspended in $50 \mu \mathrm{l} \mathrm{HBSS}$, and NP-40 was added to $1 \%$ in the presence of 40 units of the RNase inhibitor RNasin (Promega Biotec, Madison, Wis, USA). Following incubation for $1 \mathrm{~h}$ at $4^{\circ} \mathrm{C}$, the nuclei were pelleted and the supernatant was made $0.9 \mathrm{~mol} / 1 \mathrm{NaCl}, 0.09 \mathrm{~mol} / 1$ trisodium citrate, and $7 \%$ formaldehyde. After incubation at $60^{\circ}$ for $15 \mathrm{~min}$, the supernatant was spotted onto nitrocellulose (Schleicher \& Schuell, BA-85) using a minifold apparatus (Schleicher \& Schuell). The filter was baked under vacuum for $1 \mathrm{~h}$ at $80^{\circ} \mathrm{C}$ and then used for hybridization. Alternatively, the cytoplasmic supernatant was incubated for $2 \mathrm{~h}$ with proteinase K $(0.25 \mathrm{mg} / \mathrm{ml}$, Merck, Darmstadt, FRG) in $50 \mathrm{mmol} / 1$ Tris$\mathrm{HCl}(\mathrm{pH} 7.4), 60 \mathrm{mmol} / 1$ EDTA, $50 \mathrm{mmol} / 1 \mathrm{NaCl}$, and $0.5 \% \mathrm{SDS}$ at $50^{\circ} \mathrm{C}$. Following extraction with phenol and chloroform, and ethanol precipitation, the RNA was coupled to a diaminobenzoxyethyl filter (Schleicher \& Schuell) according to the manufacturer's recommendations.

A cloned fragment containing the full-length rat insulin cDNA was labelled to a specific activity of approximately $1 \times 10^{8} \mathrm{dpm} / \mathrm{ng}$ with ${ }^{32} \mathrm{P}$-dCTP by nick translation. Hybridization was overnight at $42^{\circ} \mathrm{C}$ in $50 \%$ formamide, $2 \mathrm{X}$ Denhardt's solution, $0.9 \mathrm{~mol} / 1 \mathrm{NaCl}$, $0.09 \mathrm{~mol} / 1$ sodium citrate, $50 \mathrm{mmol} / 1$ sodium phosphate $(\mathrm{pH} 6.5$ ), and $0.1 \mathrm{mg} / \mathrm{ml}$ sheared salmon sperm DNA. After hybridization, filters were washed 4 times in $15 \mathrm{mmol} / 1 \mathrm{NaCl}, 1.5 \mathrm{mmol} / 1$ sodium citrate, and $0.1 \%$ SDS at $52{ }^{\circ} \mathrm{C}$. Hybridization was visualized by autoradiography using Kodak XAR film.

\section{Statistical analysis}

Results are shown as means (or means of percentages of controls) \pm SEM. Only experiments with different islet batches were considered as separate observations. A two-tailed unpaired Wilcoxon's test was used and $5 \%$ was chosen as the level of significance.

\section{Results}

\section{Effects of IL-1 on insulin release and insulin content of isolated rat islets}

After $1 \mathrm{~h}$ of incubation with 0.5 or $5 \mathrm{U} / \mathrm{ml}$ of crude IL-1 the insulin release did not differ from control values (Table 1). After $24 \mathrm{~h}$ of exposure $0.5 \mathrm{U} / \mathrm{ml}$ caused a $63 \%$ increase $(p<0.05)$, whereas $5 \mathrm{U} / \mathrm{ml}$ resulted in a $45 \%$ decrease $(p=0.05)$ in insulin release. After an in-

Table 1. Effect of interleukin 1 on insulin release (ng insulin/10 islets) from isolated rat islets of Langerhans

\begin{tabular}{lllll}
\hline Preparation & \multicolumn{3}{l}{ Incubation period } \\
\cline { 2 - 5 } & $1 \mathrm{~h}$ & $24 \mathrm{~h}$ & 6 days \\
\hline Crude IL-1 & & & \\
Controls & $5 \pm 0.6(4)$ & $100 \pm 7(5)$ & $862 \pm 159(5)$ \\
$0.5 \mathrm{U} / \mathrm{ml}$ & $6 \pm 1.2(4)$ & $163 \pm 16^{\mathrm{a}}(5)$ & $954 \pm 141(5)$ \\
Controls & $5 \pm 0.7(4)$ & $113 \pm 23(5)$ & $693^{\mathrm{b}}$ & $(2)$ \\
$5 \mathrm{U} / \mathrm{ml}$ & $6 \pm 0.3(4)$ & $62 \pm 3^{\mathrm{a}}(5)$ & $226^{\mathrm{b}}$ & $(2)$ \\
$\mathrm{rIL}-1$ & & & & \\
Controls & & $130 \pm 13(6)$ & & \\
$0.6 \mathrm{ng} / \mathrm{ml}$ & $\mathrm{NT}$ & $198 \pm 14^{\mathrm{a}}(6)$ & $\mathrm{NT}$ & \\
$6 \mathrm{ng} / \mathrm{ml}$ & & $94 \pm 22(4)$ & & \\
\hline
\end{tabular}

Data are means and SEM of ( $n$ ) experiments, except for ${ }^{b}$, which is the mean of two experiments. NT not tested. ${ }^{a} p \leq 0.05$ 
Table 2. Effect of crude human IL-1 on total protein (TP) and (pro)insulin (PI) biosynthesis from isolated rat islets of Langerhans

\begin{tabular}{|c|c|c|c|c|c|c|}
\hline \multirow[t]{2}{*}{ Crude IL-1 } & \multicolumn{6}{|c|}{ Incubation period } \\
\hline & $T P^{a}$ & $\mathrm{PI}^{\mathrm{a}}$ & TP & PI & $\mathrm{TP}$ & PI \\
\hline $0.5 \mathrm{U} / \mathrm{ml}$ & $109 \pm 9(4)$ & $93 \pm 2(4)$ & $174 \pm 20(5)^{\mathrm{C}}$ & $145 \pm 8(5)^{\mathrm{c}}$ & $132 \pm 16(5)^{\mathrm{c}}$ & $135 \pm 16(5)$ \\
\hline $5 \mathrm{U} / \mathrm{ml}$ & $92 \pm 18(4)$ & $95 \pm 13(4)$ & $52 \pm 12(5)^{c}$ & $27 \pm 9(5)^{\mathrm{C}}$ & $38^{\mathrm{b}}$ & $22^{\mathrm{b}}$ \\
\hline
\end{tabular}

a Total protein (TP) and (pro)insulin (PI) biosynthesis (cpm/islet) are expressed in percent of respective control islets $(=100 \%)$. Data are means and SEM of $(n)$ experiments, except for ${ }^{b}$, which is the mean of two experiments. ${ }^{c} p=0.01$, when compared with respective control islets

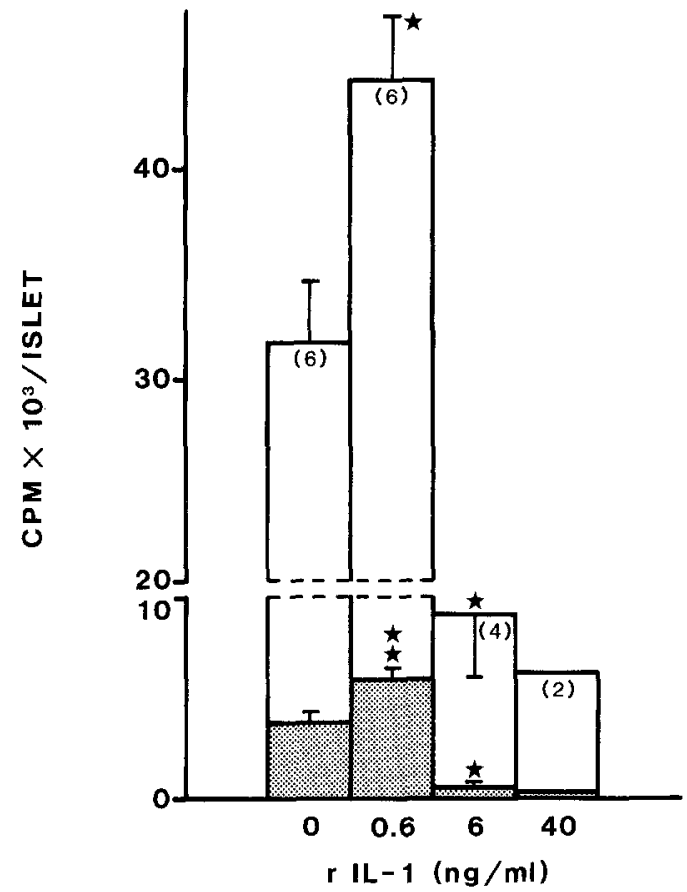

Fig. 1. Effect of rIL-1 (beta) on total protein biosynthesis (open bars) and on (pro)insulin biosynthesis (hatched bars) of isolated rat islets of Langerhans after $24 \mathrm{~h}$ of exposure. The bars represent means \pm SEM of (n) experiments. ${ }^{*} p=0.01,{ }^{*} p=0.05$ when compared with respective control islets

cubation period of 6 days, $0.5 \mathrm{U} / \mathrm{ml}$ showed no significant increase in the insulin release, while $5 \mathrm{U} / \mathrm{ml} \mathrm{de}$ creased the insulin release by $67 \%$.

Similarily, the insulin release from isolated rat islets was increased by $50 \%$ in the presence of $0.6 \mathrm{ng} / \mathrm{ml}$ rIL-1 for $24 \mathrm{~h}(p=0.02)$ while no significant decrease was observed with $6 \mathrm{ng} / \mathrm{ml}$ (NS). The insulin content of the islets exposed to $0.6 \mathrm{ng} / \mathrm{ml}$ was increased by $53 \%(p<0.025)$ while no change was observed in islets exposed to $6 \mathrm{ng} / \mathrm{ml}$ for $24 \mathrm{~h}$.

\section{Effects of IL-1 on (pro)insulin and total protein biosynthesis in rat islets}

As shown in Table 2 there was no significant difference in the total protein (TP) biosynthesis (as assessed after TCA precipitation) and the (pro)insulin biosynthesis between control islets and islets incubated with $0.5 \mathrm{U} /$ $\mathrm{ml}$ or $5 \mathrm{U} / \mathrm{ml}$ for $1 \mathrm{~h}$. After $24 \mathrm{~h}$ of exposure, both (pro)insulin and TP biosynthesis were increased by
Table 3. (Pro)insulin biosynthesis in percent of total protein biosynthesis in rat islets of Langerhans incubated with interleukin 1

\begin{tabular}{lllll}
\hline Preparation & \multicolumn{4}{l}{ Incubation period } \\
\cline { 2 - 5 } & $1 \mathrm{~h}$ & $24 \mathrm{~h}$ & 6 days \\
\hline Crude IL-1 & & & & \\
Controls & $13.7 \pm 0.7(4)$ & $15.6 \pm 0.7(5)$ & $14.5 \pm 0.5(5)$ \\
$0.5 \mathrm{U} / \mathrm{ml}$ & $11.8 \pm 1.0(4)$ & $13.5 \pm 1.5(5)$ & $15.0 \pm 0.9(5)$ \\
Controls & $21.0 \pm 2.9(4)$ & $15.6 \pm 2.4(5)$ & $15.0^{\mathrm{b}}$ & $(2)$ \\
$5 \mathrm{U} / \mathrm{ml}$ & $22.2 \pm 2.6(4)$ & $7.5 \pm 1.1(5)^{\mathrm{a}}$ & $8.9^{\mathrm{b}}$ & $(2)$ \\
rIL-1 & & & & \\
Controls & & $11.5 \pm 1.1(6)$ & & \\
$0.6 \mathrm{ng} / \mathrm{ml}$ & $\mathrm{NT}$ & $12.8 \pm 1.1(6)$ & $\mathrm{NT}$ & \\
$6 \mathrm{ng} / \mathrm{ml}$ & & $4.0 \pm 0.5(4)^{\mathrm{a}}$ & & \\
\hline
\end{tabular}

Data are means and SEM of $(n)$ experiments, except for ${ }^{b}$, which is the mean of two experiments. NT not tested. ${ }^{a} p=0.05$ when compared with respective control islets

$45 \%$ and $74 \%$, respectively, with $0.5 \mathrm{U} / \mathrm{ml}(p=0.01)$, and decreased by $73 \%$ and $48 \%$, respectively, with $5 \mathrm{U} / \mathrm{ml}(p=0.01)$.

TP but not (pro)insulin biosynthesis remained increased after 6 days of exposure to $0.5 \mathrm{U} / \mathrm{ml}$ by $32 \%$ $(p=0.01)$, and both were decreased by $62 \%$ and $78 \%$, respectively, when exposed to $5 \mathrm{U} / \mathrm{ml}$ in two experiments.

Similarily, rIL-1 at a concentration of $0.6 \mathrm{ng} / \mathrm{ml}$ significantly increased the biosynthesis of (pro)insulin by $58 \%(p=0.01)$ and TP by $40 \%(p<0.05)$ after an exposure time of $24 \mathrm{~h}$ (Figure 1 ). In contrast, $6 \mathrm{ng} / \mathrm{ml}$ of rIL-1 suppressed the biosynthesis of (pro)insulin by $89 \%(p=0.05)$ and of TP. by $68 \%(p=0.05)$, and $40 \mathrm{ng} /$ $\mathrm{ml}$ decreased the (pro)insulin and TP biosynthesis by $96 \%$ and $85 \%$, respectively, in two experiments.

As shown in Table 3, the ratio between (pro)insulin and TP biosynthesis remained unchanged in islets incubated with low doses of crude $(0.5 \mathrm{U} / \mathrm{ml})$ or rIL-1 $(0.6 \mathrm{ng} / \mathrm{ml}) .5 \mathrm{U} / \mathrm{ml}$ of crude IL-1 did not alter the (pro)insulin:TP ratio after $1 \mathrm{~h}$ of exposure. However, after an exposure time of $24 \mathrm{~h}$, both $5 \mathrm{U} / \mathrm{ml}$ of crude and $6 \mathrm{ng} / \mathrm{ml}$ of rIL-1 caused a significant decrease in the (pro)insulin: TP ratio. Similar results were obtained after an 1-h labelling period, indicating that release of newly synthesized insulin does not influence the PI/ TP ratio. Control experiments performed in the presence of $0.4 \mathrm{mmol} / \mathrm{l}$ unlabelled leucine gave the same percentual incorporation of radioactivity in (pro)insu- 


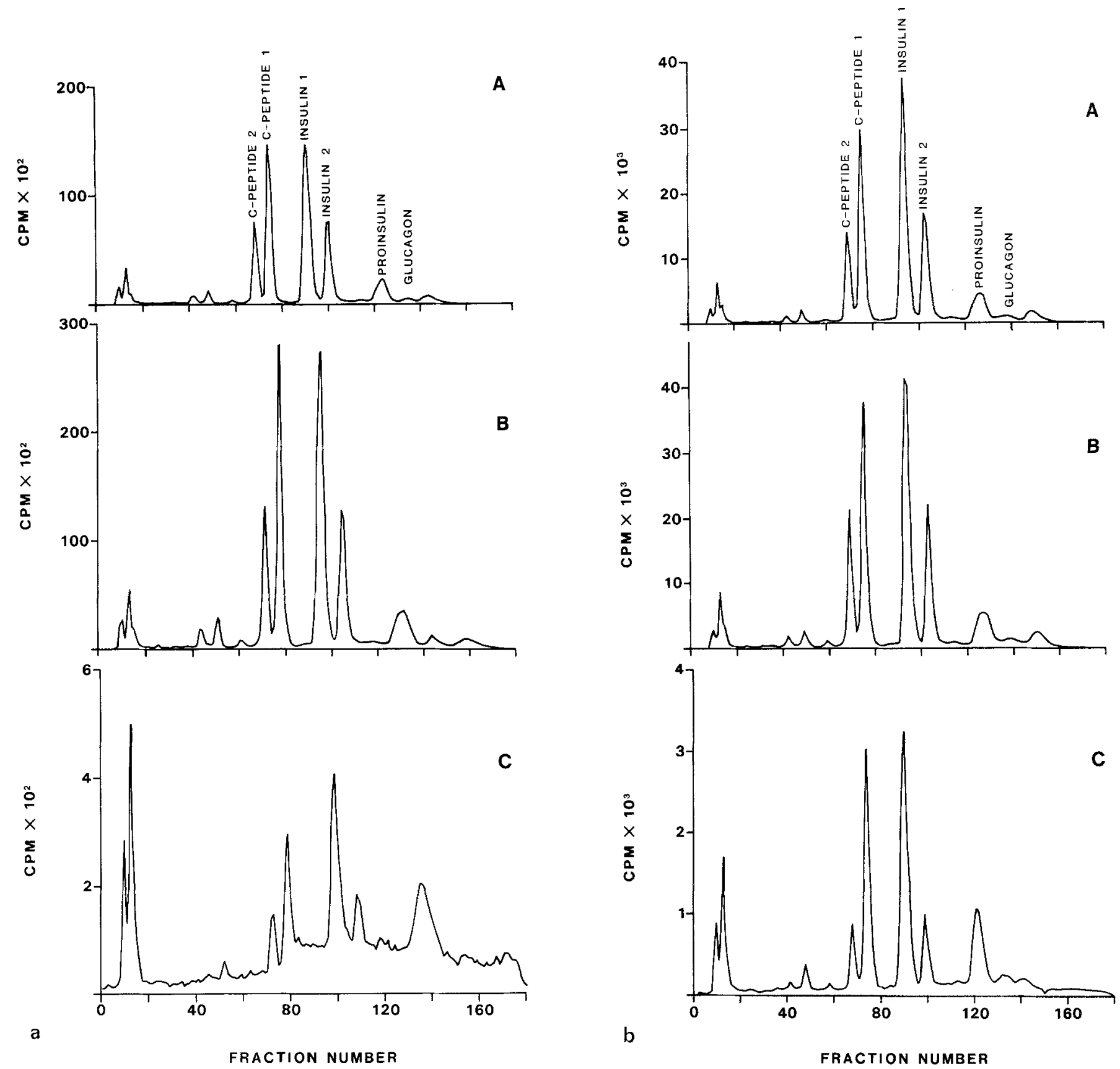

Fig. 2a and b. RP-HPLC fractionation of isolated rat islets incubated with ${ }^{3} \mathrm{H}$-leucine after a 24 -h culture period in the absence (A) or in the presence of either $0.6 \mathrm{ng} / \mathrm{ml}$ (B) or $6 \mathrm{ng} / \mathrm{ml}$ (C, extended scale) rIL-1 (beta). RP-HPLC fractionation was performed using a LiChrosorb RP-18 $(5 \mu \mathrm{m}), 250 \times 4 \mathrm{~mm}$ column eluted at $1 \mathrm{ml} / \mathrm{min}$ with TEAP/acetonitrile $(\mathrm{pH} 4.0)$. Fractions of $0.3 \mathrm{ml}$ were collected and counted for ${ }^{3} \mathrm{H}$ after addition of $2.5 \mathrm{ml}$ Aquasol (NEN). Panels a and $\mathrm{b}$ are results of two separate experiments

lin, indicating that the observed results did not depend on changes in the pool size of the aminoacid (data not shown).

\section{RP-HPLC analysis of the islet components}

The results of the separation of the ${ }^{3} \mathrm{H}$-labelled islet homogenates by means of RP-HPLC are shown in Figure 2 (panel a and b). Islets incubated with $0.6 \mathrm{ng} / \mathrm{ml}$ rIL-1 for $24 \mathrm{~h}$ showed an increase of labelled insulin 1 and 2 (more pronounced in panel a than b), C-peptide 1 and 2, proinsulin and glucagon as compared with control islets. Six $\mathrm{ng} / \mathrm{ml}$ of rIL-1 caused a marked decrease in all the fractions (most pronounced in panel b). The glucagon peak was only detectable in the experiment shown in panel $b$ (note the extended scale).

Effects of $r I L-1$ on the preproinsulin $m R N A$-content of isolated rat islets of Langerhans

As shown in Figure 3 a, the preproinsulin cytoplasmic mRNA-content of islets was unchanged after $4 \mathrm{~h}$ of exposure to $0.6 \mathrm{ng} / \mathrm{ml} \mathrm{rIL}-1$, but increased approximately 2 -fold after $24 \mathrm{~h}$ as compared with respective control 


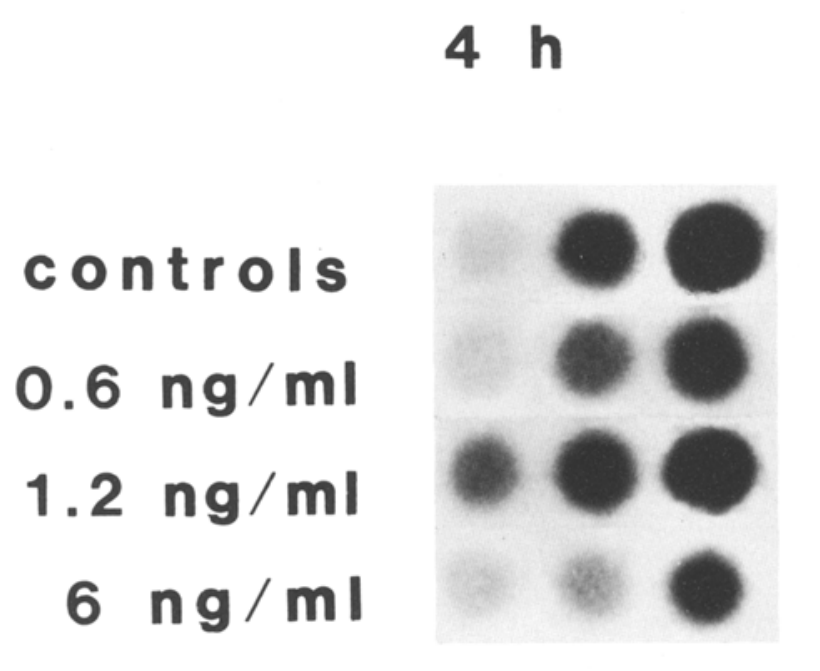

a
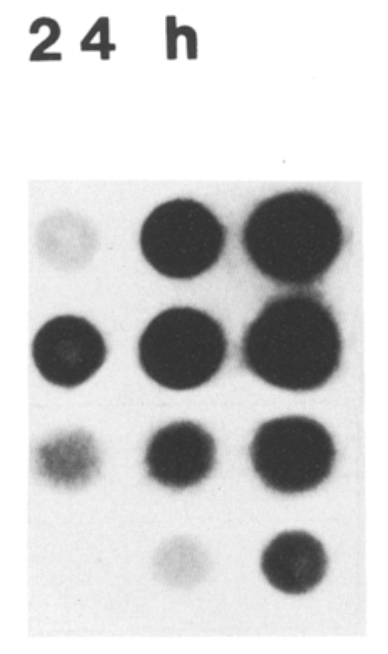

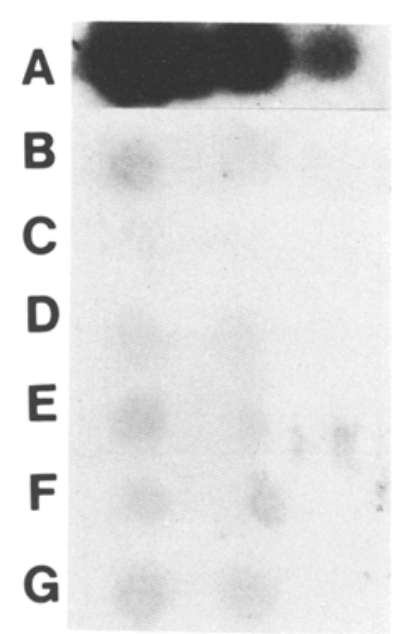

b

Fig.3. a Relative levels of pre-proinsulin mRNA of isolated rat islets of Langerhans cultured in the absence (control) or in the presence of either $0.6 \mathrm{ng} / \mathrm{ml}$, or $1.2 \mathrm{ng} / \mathrm{ml}$, or $6 \mathrm{ng} / \mathrm{ml}$ of rIL-1 (beta) for 4 and $24 \mathrm{~h}$ are shown. From left to right, total cytoplasmic RNA from 30,60 , and 120 islets was denatured and spotted onto filters, and hybridized with rat insulin cDNA as described under Methods. b Control hybridizations to (B) testis total RNA, (C) testis poly A+ RNA, (D) liver total RNA, (E) kidney total RNA, (F) kidney poly A+ RNA, and (G) spleen total RNA are shown. 10, 5, and $2.5 \mu \mathrm{g}$ RNA was used, respectively, which was in vast excess of the amount of RNA from 120,60 , and 30 islets on the same film (A)

islets. $1.2 \mathrm{ng} / \mathrm{ml} \mathrm{rIL}-1$ increased the mRNA-content by $4 \mathrm{~h}$, but decreased it after $24 \mathrm{~h}$ of exposure. Six $\mathrm{ng} / \mathrm{ml}$ rIL- 1 caused a slight decrease in mRNA by $4 \mathrm{~h}$ and an approximately 2 -fold decrease after $24 \mathrm{~h}$ of incubation. Similar results were observed using two different methods of coupling the RNA preparations to filters (see Methods). In Figure $3 \mathrm{~b}$ are shown control hybridizations with RNA preparations from various tissues (see legend to Figure $3 b$ ).

\section{Discussion}

IL-1 is the major inducer of acute phase responses associated with infection or inflammation and thereby exerts stimulatory and proliferative effects on various unrelated cell types. Besides the activation of T- and Bcells, it stimulates chondrocytes to release collagenase and neutral proteases $[19,20]$, induces the biosynthesis of procoagulant activity in endothelial cells [21], increases acute phase protein synthesis in hepatocytes [22], and collagen type IV production in epidermal cells [23]. A cytotoxic action of the cytokine has been reported for certain tumour cell lines [24, 25], and for pancreatic $B$ cells $[5,6]$.

In previous reports we could show that low IL-1 concentrations increase and high IL-1 concentrations decrease, insulin release as well as insulin content in isolated rat islets of Langerhans $[4,5]$. The present data demonstrate that human IL-1 dose- and time-dependently affects the biosynthesis of (pro)insulin in rat islets. Low concentrations of IL-1 increase, and high concentrations decrease the biosynthesis of (pro)insulin. In addition, the relative level of preproinsulin
mRNA is increased in islets exposed to low IL-1 concentrations and decreased after exposure to high IL-1 concentrations.

High IL-1 concentrations and prolonged exposure time to the agent, i.e. $5 \mathrm{U} / \mathrm{ml}$ of crude or $6 \mathrm{ng} / \mathrm{ml}$ of rIL-1 for $24 \mathrm{~h}$, cause a significant reduction of the (pro)insulin biosynthesis when calculated as a percentage of the total protein biosynthesis. On the other hand, low IL-1 concentrations, i. e. $0.5 \mathrm{U} / \mathrm{ml}$ of crude or $0.6 \mathrm{ng} / \mathrm{ml}$ of $\mathrm{rIL}-1$, or an incubation of $1 \mathrm{~h}$ with $5 \mathrm{U} / \mathrm{ml}$ do not alter the ratio of (pro)insulin to TP. These results indicate that low concentrations of IL-1 exert a non-specific stimulatory action on the isolated islet organ. In contrast, higher concentrations or a longer exposure time to the agent cause a marked perturbation of the differentiated function of the B cell, i. e. insulin production, whereas the non-insulin related proteins are less affected.

Furthermore, HPLC analysis of the islet proteins revealed changes in all the fractions including glucagon and proinsulin. However, if a proinsulin to insulin ratio is calculated on a molar basis (taking into account the different number of leucine residues of proinsulin and insulin), this ratio is found to be increased three-fold (33 and 20 in Figure 2 a, b respectively) in islets incubated with high concentrations of IL-1 as compared with control islets (8.5 and 8.4) and islets incubated with a low IL-1 concentration (9.8 and 9.6). It seems unlikely that this is due to increased secretion of newly synthesized insulin during the labelling period, since the insulin release was decreased at the high IL-1 concentration. Preliminary pulse-chase experiments have confirmed the reduced rate of conversion at the high IL-1 concentration [16]. 
A dose- and time-dependent bimodal effect of IL-1 on protein biosynthesis of normal cells has recently been observed in rat osteoblasts. While IL-1 concentrations of $0.1-5 \mathrm{U} / \mathrm{ml}$ were found to stimulate calvarial collagen and non-collagen protein synthesis, higher doses or longer exposure time to IL-1 had an inhibitory effect on the synthesis of collagen [26].

In islet cells, dual dose-dependent effects on insulin release and insulin content have been reported for hydrocortisone as well. At near physiological concentrations, i.e. $10^{-7} \mathrm{~mol} / 1$, hydrocortisone stimulated both insulin release and insulin content in rat [27] as well as preproinsulin mRNA, proinsulin biosynthesis and insulin release in mouse islets $[28,29]$. Higher hydrocortisone concentrations $\left(10^{-5} \mathrm{~mol} / \mathrm{l}\right)$, however, failed to stimulate insulin release and insulin content in either rat or mouse islets.

The changes in preproinsulin mRNA demonstrate that IL-1 acts at a pretranslational level of insulin biosynthesis. Since we only measured steady-state mRNA levels, we cannot say whether IL-1 triggers the transcription of the insulin gene(s) or inhibits the degradation of mRNA. It can be ruled out that IL-1 increases mRNA by inducing DNA replication and cell division, since we have previously observed that although IL-1 at low concentrations increased the islet insulin content, the DNA content of the islets remained unchanged [4]. This was also found in rat osteoblasts, where IL-1 was shown to stimulate collagen and noncollagen protein synthesis in the presence of hydroxyurea, which blocks DNA-replication [26].

A stimulatory effect on the transcription of the insulin gene(s) has been reported for glucose in normal rat islets and for cholera toxin in the insulin-producing cell line RIN-5 F [30, 31]. In these studies it was demonstrated that in addition to a stimulation of the insulin gene(s) transcription, cyclic AMP mediated inhibition of mRNA degradation played an important part in increasing specific mRNA levels. Since a stimulation of insulin release at low IL-1 concentrations has been found in the presence of high but not low glucose concentrations $[4,32,33]$, it is possible that IL-1 may act by potentiating glucose effects both at pre- and post-translational levels.

However, IL-1 in itself can act at the pretranslational level of protein biosynthesis, as recently shown by Ramadori et al. [22]. In mouse hepatocytes IL-1 increased serum amyloid A and factor B, yet decreased albumin synthesis at the transcriptional level.

At high IL-1 concentrations, the decrease in preproinsulin mRNA may, together with the inhibited biosynthesis of (pro)insulin and the decreased insulin secretion, merely reflect a toxic effect of IL-1 on B-cell function.

In vivo counterparts of the observed dose-dependent biologic response of islet cells to IL-1 may hypothetically exist. Low circulating IL-1 concentrations may have an endocrine effect and increase insulin se- cretion as has been observed during the acute phase response induced by infection or in experimental animal models, where hyperinsulinaemia occurs with a time lag of $4 \mathrm{~h}$ after injection of endotoxin or $1 \mathrm{~h}$ after injection of crude IL-1 preparations into rats $[34,35]$. Furthermore, IL-1 may play a role in priming the physiological secretion of insulin, since prevention of the "normal" low grade portal endotoxemia by diminishing intestinal derived endotoxin in rats results in decreased basal and stimulated insulin levels [36].

When IL-1 is produced in high concentrations in situ, i. e. as a part of the insulitis process, it may be toxic to B cells and cause insulin-dependent diabetes mellitus. The possible mechanisms involved in this process have been reviewed [33]. A crucial point is the specificity of the IL-1 action. The stimulatory effect does not appear to be B-cell specific, but there are certain indications for a particular susceptibility of the B cell to the toxic effect of IL-1. Although the total protein biosynthesis is inhibited after 24-h exposure to high IL-1, (pro)insulin biosynthesis is more affected. Because of the marked time dependence of the IL-1 effect, resulting in early stimulation by any dose of IL-1 and later inhibition depending of the dose [32,33], a more differentiated time-course must be considered. Recently a morphological time-course study showed that B cells were subjected to pathological changes already after $30 \mathrm{~min}$ exposure to IL-1, while no changes in A-cell morphology was observed during 24-h exposure [37]. Thus, a short half-life of IL-1 in vivo together with a high local concentration may create conditions for a selective destruction of the B cells.

In summary we have demonstrated that low IL-1 concentrations increase preproinsulin mRNA, (pro)insulin biosynthesis and insulin secretion indicating preand post-translational effects of the cytokine. Higher IL-1 concentrations or prolonged exposure to the agent, however, decrease preproinsulin mRNA, (pro)insulin biosynthesis and insulin secretion and possibly conversion of proinsulin to insulin, reflecting a sick cell.

Acknowledgements. A. B.Andersen and S.Grinderslev are thanked for skillful technical assistance. This work was supported by the Swiss National Science Foundation (GAS), Nordisk Insulinlaboratorium (BSH, TMP), and the Michaelsen Foundation (TMP).

\section{References}

1. Dinarello CA (1984) Interleukin-1. Rev Inf Dis 6: 51-95

2. Dinarello CA (1986) Interleukin-1: amino acid sequences, multiple biological activities and comparison with tumor necrosis factor (cachectin). Year Immunol 2: 69-89

3. Oppenheim JJ, Kovacs EJ, Matsushima K, Scott KD (1986) There is more than one interleukin 1. Immunol Today 7:27-63

4. Spinas GA, Mandrup-Poulsen T, Mølvig J, Bæk L, Bendtzen K, Dinarello CA, Nerup $J$ (1986) Low concentrations of interleukin-1 stimulate and high concentrations inhibit insulin release from isolated rat islets of Langerhans. Acta Endocrinol 113: $551-558$ 
5. Mandrup-Poulsen T, Bendtzen K, Nerup J, Dinarello CA, Svenson M, Nielsen JH (1986) Affinity-purified human interleukin-1 is cytotoxic to isolated islets of Langerhans. Diabetologia 29: 63-67

6. Bendtzen K, Mandrup-Poulsen T, Dinarello CA, Nerup J, Nielsen JH, Svenson M (1986) Cytotoxicity of human pI 7 interleukin-1 for pancreatic islets of Langerhans. Science 232: 1545-1547

7. Mandrup-Poulsen T, Bendtzen K, Nielsen JH, Bendixen G, Nerup J (1985) Cytokines cause functional and structural damage to isolated islets of Langerhans. Allergy 40: 424-429

8. Mandrup-Poulsen T, Bendtzen K, Nerup J, Egeberg J, Nielsen JH (1986) Mechanisms of pancreatic islet cell destruction: dose-dependent cytotoxic effect of soluble blood mononuclear cell mediators on isolated islets of Langerhans. Allergy 41: 250-259

9. Dinarello CA, Cannon JG, Mier JW, Bernheim HA, LoPreste GM, Lynn DL, Love RN, Webb AC, Auron PE, Reuben RC, Rich A, Wolff SM, Putney SD (1986) Multiple biological activities of human recombinant interleukin-1. J Clin Invest 77: $1734-1739$

10. Brunstedt J, Nielsen JH, Lernmark $\AA$, The Hagedorn Study Group (1984) Isolation of islets from mice and rats. In: Larner J, Pohl SL (eds) Methods in diabetes research, Vol 1. Laboratory methods, part C. John Wiley, New York, pp 254-258

11. Heding $L$ (1972) Determination of total serum insulin (IRI) in insulin-treated diabetic patients. Diabetologia 8: 260-266

12. Brunstedt J, Chan SJ (1982) Direct effect of glucose on the preproinsulin mRNA level in isolated pancreatic islets. Bioch Biophys Res Comm 106: 1383-1389

13. Halban PA, Wolheim CB (1980) Intracellular degradation of insulin stores by rat pancreatic islets in vitro. J Biol Chem 255: 6003-6006

14. Berne C (1975) Anti-insulin serum coupled to Sepharose $4 B$ as a tool for investigation of insulin biosynthesis in the $\beta$-cells of obese-hyperglycemic mice. Endocrinology 97: 1241-1247

15. Welinder BS, Linde S, Hansen B (1985) Reversed-phase highperformance liquid chromatography of insulin and insulin derivatives. J Chromatogr 348: 347-361

16. Linde S, Nielsen JH, Hansen B, Welinder BS (1987) RP-HPLC analysis of the insulin biosynthesis in isolated rat islets. 11th International Symposium Column Liquid Chromatography, Amsterdam, June 28-July 3, 1987, Abstract Fr-P-37

17. Halban PA, Rhodes CJ, Shoelson SE (1986) High performance liquid chromatography: a rapid, flexible, and sensitive method for separating islet proinsulin and insulin. Diabetologia 29: 893-896

18. White BA, Bancroft FC (1982) Cytoplasmic dot hybridization. J Biol Chem 257: 8569-8572

19. Saklatvala J, Pilsworth S, Sarsfield SJ, Gavrilovic J, Heath JK (1984) Pig catabolin is a form of interleukin-1. Biochem J 224: 461-466

20. Gowen M, Wood DD, Ihrie EJ, Meats JE, Russel RGG (1984) Stimulation by human interleukin-1 of cartilage breakdown and production of collagenase and proteoglycanase by human chondrocytes but not human osteoblasts in vitro. Biochim Biophys Acta 797: 186-193

21. Bevilacqua MP, Pober JS, Majeau GR, Cotran RS, Gimbrone MA Jr (1984) Interleukin 1 induces biosynthesis and cell surface expression of procoagulant activity on human vascular endothelial cells. J Exp Med 160: 618-623

22. Ramadori G, Sipe JD, Dinarello CA, Mizel SB, Colten HR (1985) Pretranslational modulation of acute phase hepatic protein synthesis by murine recombinant interleukin- 1 and purified human IL-1. J Exp Med 162: 930-942
23. Matsushima K, Bano M, Kidwell WR, Oppenheim JJ (1985) Interleukin 1 increases collagen type IV production by murine mammary epithelial cells. J Immunol 134: 904-909

24. Onozaki K, Matsushima K, Aggarwal BB, Oppenheim JJ (1985) Human interleukin 1 is cytocidal factor for several tumor cell lines. J Immunol 135: 3962-3968

25. Lachmann LB, Dinarello CA, Llansa ND, Fidler IJ (1986) Natural and recombinant human interleukin 1 beta is cytotoxic for human melanoma cells. J Immunol 136: 3098-3102

26. Canalis $E$ (1986) Interleukin-1 has independent effects on deoxyribonucleic acid and collagen synthesis in cultures of rat calvariae. Endocrinology 118: 74-81

27. Nielsen JH (1983) Hormonal regulation of growth and function of insulin-producing cells in culture. In: Fischer G, Wieser RJ (eds) Hormonally defined media. A tool in cell biology. Springer, Berlin Heidelberg New York Tokyo, pp 264-273

28. Brunstedt J (1982) Expression of the insulin gene: regulation by glucose, hydrocortisone and growth hormone in mouse pancreatic islets in organ culture. Acta Biol Med Germ 41: 1151-1155

29. Brunstedt J, Nielsen JH (1981) Direct long-term effect of hydrocortisone on insulin and glucagon release from mouse pancreatic islets in tissue culture. Acta Endocrinol 96: 498-504

30. Nielsen DA, Welsh M, Casadaban MJ, Steiner DF (1985) Control of insulin gene expression in pancreatic beta cells and in an insulin-producing cell line, RIN-F5 cells. I. Effects of glucose and cyclic AMP on the transcription of insulin mRNA. J Biol Chem 260: 13585-13589

31. Welsh M, Nielsen DA, McKrell AJ, Steiner DF (1985) Control of insulin gene expression in pancreatic beta cells and in an insulinproducing cell line, RIN-5F cells. II. Regulation of insulin mRNA stability. J Biol Chem 260: 13590-13594

32. Zawalich WS, Diaz VA (1986) Interleukin 1 inhibits insulin secretion from perifused rat islets. Diabetes $35: 1119-1123$

33. Nielsen JH, Mandrup-Poulsen T, Spinas GA, Hansen BS, Mølvig J, Nerup J, Bendtzen K (1986) Possible role of interleukin-1 (IL-1) in the pathogenesis of insulin-dependent diabetes mellitus (IDDM). In: Jaworsky MA (ed) The immunology of diabetes mellitus. Elsevier, New York pp 95-103

34. Cornell RP (1983) Role of the liver in endotoxin-induced hyperinsulinemia and hyperglucagonemia in rats. Hepatology 3: 188-192

35. George DT, Abeles FB, Mapes CA, Sobocinski PZ, Zenser TV, Powanda MC (1977) Effect of leucocytic endogenous mediators on endocrine pancreas secretory responses. Am J Physiol 233: E240-E 245

36. Cornell RP (1985) Endogenous gut-derived bacterial endotoxin tonically primes pancreatic secretion of insulin in normal rats. Diabetes 34: 1253-1259

37. Mandrup-Poulsen T, Egeberg J, Nerup J, Bendtzen $K$, Nielsen JH, Dinarello CA (1987) Ultrastructural studies of timecourse and cellular specificity of Interleukin-1 mediated islet cytotoxicity. Acta Pathol Microbiol Immunol Scand [C] 95: $55-63$

Received: 17 December 1986

and in revised form: 1 June 1987

Dr. J. Nerup

Steno Memorial Hospital

Niels Steensensvej 2

DK-2820 Gentofte

Denmark 